\title{
The First International in Switzerland
}

\section{A Few Observations}

\author{
Marc Vuilleumier \\ Translation by Angèle David-Guillou
}

Considering the circumscribed nature of this study, we will limit ourselves to a few points. ${ }^{1}$ The early presence of the International in Switzerland and, from its beginnings, the extent of its exchanges with other countries are due to the networks of personal relations which interlinked some of its first protagonists. The case of Johann Philipp Becker is known, ${ }^{2}$ that of doctor Pierre Coullery less so, partly a consequence of the depreciative comments James Guillaume voiced about him; though Guillaume himself was rather ill-informed about Coullery's formative years. ${ }^{3} \mathrm{~A}$ former representative of this movement that in Switzerland, around the year 1850, corresponded to that of "démocrates-socialistes" in France, Coullery had maintained contacts with the refugees he had known in Switzerland, many of whom were ultimately expelled to other countries. This allowed him to play a prime role in the meetings of European democrats that were held discreetly and carefully amidst crowds gathered for some official celebration: the Federal Shooting Festival at La Chaux-de-Fonds (12-22 July 1863),

1 In our notes, we limit ourselves to specific studies and archives. We have ignored any reference to studies well known to historians: L'Internationale by J. Guillaume for instance. Regarding the minutes of the General Council, the dates stated will allow easy referencing to the passage in the document. On the occasion of the 1964 centenary, we had presented a general overview of the IWMA in Switzerland: Marc Vuilleumier: "La Première Internationale en Suisse", La Première Internationale. L'institution. L'implantation. Le rayonnement. Paris, 16-18 novembre 1964 (Paris, 1968), pp. 231-250, as well as a version intended for the readers of Revue syndicale suisse, later used in our Histoire et combats (Lausanne, 2012), pp. 115-130. Erich Gruner, Die Arbeiter in der Schweiz im 19. Jahrhundert (Bern, 1968) makes for an indispensable read, thanks to the width of its documentation, but a difficult one as what concerns the IWMA is disseminated across different chapters often dealing with other subjects. Since then, only a few specific studies have been published, about the Jura federation notably.

2 Gruner in Die Arbeiter in der Schweiz used with great results his prolific correspondence. See also: Hans-Werner Hahn (ed.), Johann Philipp Becker. Radikaldemokrat-RevolutionsgeneralPionier der Arbeiterbewegung (Stuttgart, 1999).

3 Despite the meticulous and remarkable study by Elfriede Wiss-Belleville, Pierre Coullery und die Anfänge der Arbeiterbewegung in Bern und der Westschweiz. Ein Beitrag zur Geschichte des Schweizerichen Frühsozialismus (Basel [etc.], 1987). 
the Independence festivities in Brussels (26-29 September 1863). If the Association fédérative universelle which came out of these encounters was short-lived, it connected or reconnected individuals who would later resurface amongst the International Workingmen's Association: Léon Fontaine and Brismée for Belgium; Coullery, Karl Bürkli and Becker for Switzerland. In addition, Valentin Weber, a German watchmaker, was delegated by the London Arbeiterbildungsverein (Workers' Educational Society) to Brussels, on Marx's suggestion, to intervene in favour of Poland. This same Weber had taken part in the Baden Uprising of 1849, and had gone over to Switzerland with what was left of the revolutionary army. It was at this time that he had met Becker, and perhaps Coullery who, in Geneva, had been in close contact with the German exiles. ${ }^{4}$

Coullery's networks of relationships were the source of the international flavour that he gave his journal, La Voix de l'Avenir. When Le Confédéré of Fribourg, which for its foreign part was in the hand of a group of French republicans, criticized Brismée for denouncing the verbal violence French students deployed during the Liege congress, at a meeting organised with them on 3 November 1865, Coullery wrote a reply, defending the Belgian man "I know" - even if he did not share all of his ideas. ${ }^{5}$ Coullery's acquaintances in France are more difficult to trace. He could have benefited from the network of Claude François Marchand, an exile of 2 December 1851, established as a veterinary doctor in Locle, a naturalised Swiss citizen and president of the local branch of Helvetia, this radical left association which had not remained foreign to the 1863 congress. In 1848-1849, Marchand had been very involved in the revolutionary movements in Lyon, where he seemed to have kept numerous relations. And so La Voix de l'Avenir was particularly interested in this city, taking in numerous articles by the young Albert Richard and, after the International Workingmen's Association's (IWMA) Congress in Geneva, publishing the report of Lyon's representatives which had been withdrawn in favour of their Parisian counterparts' and which, for this reason, did not appear in the minutes of the Congress. ${ }^{6}$ Coullery expressed some reservations about the report, "but $[\ldots]$

4 Wiss-Belleville, Pierre Coullery; MEgA III/12; John Bartier, Libéralisme et socialisme au XIXe siècle, studies collated and published by Guy Cambier (Bruxelles, 1981), pp. 313-341.

5 Le Confédéré (17 November 1865); La Rive Gauche (26 November 1865).

6 Ten excerpts from the Mémoire were published between 4 November 1866 and 20 January 1867. On 2 December 1866, a correspondence signed by "Several workers" ("Plusieurs ouvriers") indicates that, during a discussion on the social question, one of them read the Lyon workers' Mémoire, giving rise to varied comments. A manuscript copy of the 34 pages can be found in the Jung archive at the IIsH. We have not been able to compare it with the texts published by La Voix de l'Avenir, which seem to account for almost its entirety. Maurice Moissonnier analysed the Amsterdam document on pages 54-55 of La Première Internationale et 
one will find on each page the expression of this idea, this feeling, which will make the proletariat all-powerful, that the working classes must look for their salvation in themselves."

Despite Coullery's connections, it was without his involvement that the first group of the International was created in Switzerland. Already, on 11 October 1864, a few workers from Geneva informed Tolain in Paris of the constitution of a temporary committee in charge of contacting the Association. Amongst them was Dupleix the binder, a French republican who had taken refuge in Switzerland after the coup of 2 December 1851 . Why Tolain rather than London directly? Were there links between the older republican exiles from Geneva and Paris, perhaps via H. Lefort? During the traditional 1848 anniversary banquet, on 24 February 1865, French republicans and their friends from other countries discussed the International, which five local associations had joined. Did Becker take part in these early activities? His articles for Nordstern of Hamburg, in which he recounts the beginnings of the IWMA in Geneva, would suggest so, although he was then absorbed in his political activities amongst the German diaspora and Swiss radical Left associations (Helvetia). On 25 April 1865, when the Association gathered 200 members in Geneva and a General Council of fifteen with an executive of seven people was formed, the Central Committee nominated Dupleix, Becker and Falconnet as correspondents for Switzerland. The IWMA was providing existing labour associations with the possibility to join collectively. And indeed, on 5 February, the Genevan committee had sent all labour organisations a circular in French and another one in German, to which the provisional rules of the Association were adjoined, asking them to discuss and consider the possibility of becoming members. It was this circular which Coullery reproduced in the radical journal of La Chaux-de-Fonds on 25 March, and which prompted him to create the first section of the JuraNeuchâtel region. On 21 November, the General Council nominated him as a correspondent. At the same time, Becker was speaking to the German Federation of labour associations in Switzerland and to its local branches, to Grütli, a radically inclined popular Swiss association which had numerous local bureaux, as well as to the German-speaking organisations he was in contact with in other countries, thus laying the basis of what would become the IWMA's German-speaking group, with its monthly publication, Der Vorbote (1866-1871).

Other networks played a part in the beginnings of the International: Pierre Vésinier's, in Switzerland then later in Brussels and London, was one of them.

la Commune à Lyon (1865-1871) (Paris, 1972), insisting, perhaps too heavily, on its Proudhonist character. Albert Richard's numerous articles for Coullery's paper have not been taken into account by historians. 
Vésinier was a somewhat equivocal character, whose actions were often met with hostility. He had taken refuge in Switzerland in the wake of 2 December, and there had led conspiracy activities within the exile community as well as in the field of local political struggles in Geneva, resulting in him being expelled. He joined the IWMA in Brussels, then the Concorde lodge (merged with that of the Philadelphes) in London where he met two members of the IWMA: Nüsperli from Switzerland and Le Lubez from France (convener of the French branch). It was with the latter that Vésinier accused the IWMA's Parisian officials of "Bonapartism", initiating a long-lasting dispute which ended with both of them being excluded. This opposition had its repercussions in Switzerland where, in Geneva, an informal group (formed of republicans opponents to Dupleix, progressive local politicians though enemies of the radical leader James Fazy) took stance against the International. When Blanqui came to Switzerland (19 May/3 November 1866), he had no contacts there apart from those which Vésinier provided him with. All the contacts he made in Geneva were thus with Vésinier's friends. In La Chaux-de-Fonds, where Blanqui spent the first summer month, he stayed with Coullery, although condemning his cooperative leanings and the International. The incident of the Geneva congress of September 1866, during which Blanqui's supporters attempted, in vain, to be allowed in, is well-known. ${ }^{7}$

Identifying the reasons why pre-existing labour associations would become affiliated to the IWMA is not always easy, but a few primary sources provide us with some clarifications. Generally speaking, the example set by the most powerful unions in England, as well as the solidarity both facilitated and put into practice by the IWMA, impressed and pulled them in. So did the prospect of being supported during future wage disputes; a point made very apparent from the study of the minutes of the Union of Typographers in Geneva. Three out of the first four IWMA congresses having taken place in Switzerland, the representatives of the General Council were able to use their visits to hold meetings with their local colleagues, sometimes organising tours around the entire country. All these efforts gave local associations the assurance that they were not alone in the event of protests and strikes, and ultimately incited them to join in and encouraged the workers of certain trades, not yet organised, to form sections of the International.

7 Marc Vuilleumier, "Associationnisme ouvrier, républicains et blanquistes au début de la Première Internationale (1864-1866)", in Michel Cordillot, Claude Latta (ed.), Benoît Malon le mouvement ouvrier, le mouvement républicain à la fin du Second Empire (Lyon, 2010), pp.

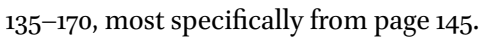


We should beware the labels so readily applied to the militants of the IWMA, such as that of Proudhonist attached to Coullery. His socialism, it has been said, originated from the "démocrates-socialistes" of the years 1849-1850, where the influences of the various schools of thought mingled. Even the concept of federalism, very present in his discourse, owed more to what he experienced between 1848 and $185^{1}$ than to Proudhonist theories. ${ }^{8}$ During the spring of 1866, the shoemakers of La Chaux-de-Fonds stopped working in order to obtain the right to take their meals away from their employers' table. La Voix de l'Avenir, whilst remaining perplexed as to why such a right could be contested, noted that striking was an empirical means which did not lead to the aim it sought and could even be dangerous for more than one industry. "But striking has an incontestable result, it gives courage to the worker, it develops in him the feeling of power and it prompts meetings where social questions are discussed and explored thoroughly. Strikes in England generated those numerous workers' associations which today send tremors through the English aristocracy. Therefore, we believe strikes to be powerless in addressing the working classes' wretchedness, but they show the road to progress, they lead to associations." ${ }^{\prime 9}$ A similar commentary regarding a shoemakers' strike in Geneva was published shortly after: "This means of remedying our evils, powerless in essence, has the salutatory effect of making the worker think and discuss." But "only the forming of associations can regenerate the working classes. [...] Thus, let us swap strikes for associations."10 In September 1866, when the workers of the Japy clock-making factories in Beaucourt and its surroundings (in France, not far from the Swiss border) stopped their activity to oppose a cut in wages, Coullery restated his position that striking was an "imperfect and transitory weapon."11 Noting that Japy was trying to monopolise the making of sketches,

8 We are referring here to a very old study which would benefit from an in-depth update: Marc Vuilleumier, "Théophile Thoré et les républicains français réfugiés en Suisse de 1849 à 1851", Revue suisse d'histoire, 14 (1964), fasc. 1, pp. 1-32.

9 "Mais la grève a un résultat incontestable, elle donne du courage à l'ouvrier, elle développe en lui le sentiment de la puissance et elle provoque des réunions où les questions sociales sont discutées et approfondies. Les grèves, en Angleterre, ont engendré ces nombreuses sociétés ouvrières qui aujourd'hui font trembler l'aristocratie anglaise. Ainsi, nous croyons les grèves impuissantes à remédier à la misère des classes laborieuses, mais elles tracent la voie du progrès, elles conduisent aux associations." La Voix de l'Avenir (20 May 1866).

"Ce moyen impuissant en lui-même pour remédier à nos maux, a pour effet salutaire de faire réfléchir et discuter l'ouvrier. [...] [mais] L'association seule peut régénérer les classes ouvrières. [...] Donc, remplaçons la grève par l'association."

"Arme imparfaite et transitoire." 
which would not be without consequences for the clock assemblers of La Chaux-de-Fonds, he considered that the Swiss workshops should welcome the French strikers. "Workers of Switzerland, let us express our admiration to those working-men who prefer wretchedness to the unbearable conditions imposed on them". ${ }^{12}$ Those few examples show how over-simplistic certain labels are. One can at once condemn the principle of striking and support its manifestations, by acknowledging what they bring to labour consciousness and to the feeling of solidarity.

It was in the name of solidarity that the first sections of the IWMA were created in Switzerland and that they gave support to local strikers but also, from an early stage, to those abroad. On 27 March 1867, the Central Committee for French-speaking Switzerland in Geneva sent a four-page circular regarding the bronze-workers' strike in Paris. After a short historical introduction, it reproduced the resolution taken by the IWMA General Assembly in Geneva: 100 francs interest-free loan; permanent subscription; call for all the Frenchspeaking Swiss labour associations to do the same. The document was able to lay out results: forty-six francs ninety; the Carouge section loaned twenty francs and had gathered eighteen francs from a subscription; the Germanspeaking section of Geneva had agreed to 100 francs in loan and had launched a subscription too. To put these figures in perspective, let us remind that the average daily wage was three francs sixty for construction workers and in excess of five francs for clockmakers.

At the turn of 1868 , a strike of engravers took place, ${ }^{13}$ this time in Geneva. Six sections agreed to interest-free loans amounting to 220 francs (German-speaking section, joiners, tinsmiths, carpenters, stonecutters and bricklayers, cabinetmakers). Surprisingly, clockmakers were absent from this demonstration of solidarity. Subscriptions from various sections had raised 290.85 francs, including 206.05 francs from the jewellers alone. Thus the engravers' treasurer was handed 360 francs, from which two francs and a half had been deducted to pay for the printing of the poster calling for a general assembly of the sections which had shown their support. A surplus of 510.85 francs remained, well enough to pay the loans back. The well-researched great construction-workers' strike, which was taken over by the Central Committee, is worth mentioning considering its strength and the monies

12 "Ouvriers de la Suisse, exprimons notre admiration à ces ouvriers qui préfèrent la misère aux conditions impossibles qu'on veut leur imposer." La Voix de l'Avenir (23 September 1866). See also La Voix de l'Avenir (2 April 1867).

13 All the documents used below come from the archives of the Genevan typographers' union held at the Bibliothèque de Genève [hereafter BGE]. 
involved. Subscription-wise, the Central Committee had received 6,503.6o francs: forty per cent of which came from the clock-making and jewellery factory ("La Fabrique"); nine per cent from other Genevan sections; eleven per cent from the rest of French-speaking Switzerland; nineteen per cent from France (almost entirely from Paris); thirteen per cent from Germany and German-speaking Switzerland (not differentiated) and seven per cent from London and Berlin. In addition, 15,583.50 francs in interest-free loan were raised, of which twenty-two per cent was granted by clockmakers and jewellers; eleven per cent by other Genevan sections; fifty-four per cent by Paris and five per cent by London. The importance of donations and loans from France was for the most part due to the engraver François Graglia, sent to Paris and London (315 francs in expenses). He was able to befriend several members of the Federal Commission of Paris. In London, he had not been able to receive the help he had hoped for, the status of English associations making immediate unexpected payments impossible. "Undoubtedly," he wrote to Varlin, "I am the first to admit it, in a few weeks these same societies would provide more money than our needs require."14 Finally, 13,437.80 francs were handed to the sections of locksmiths, painters-plasterers, stonecutters and bricklayers, bardeurs ${ }^{15}$ and unskilled workers, tinsmiths and French and German-speaking carpenters and joiners. The sum, it seems, was distributed proportionally between the sections according to their size $-4,383$ francs for the stonecutters and bricklayers alone. Each striker received a daily compensation of one franc fifty, then finally only zero franc seventy-five. In fact, many had already left Geneva, especially the seasonal unskilled workers of neighbouring Faucigny.

The relations created on this occasion remained strong until after the trial of the second Commission du bureau de Paris, in May-June 1868. A report from the typographers' delegate, read in front of his section during the Central Committee's meeting, shows that the Committee had published an address opposing the legal actions against the Parisian detainees and their sentence to three-month imprisonment. ${ }^{16}$ "In addition the Committee has decided to start

14 "Sans doute, je suis le premier à le reconnaître, dans quelques semaines ces mêmes sociétés nous fourniraient des sommes supérieures à nos véritables besoins." Procès de l'AIT. Première et deuxième Commission du Bureau de Paris ... (Paris, 1870), p. 139. One can also find here the correspondence received by Varlin from the Genevan Internationalists (Les Internationaux de Genève).

15 Workers who were in charge of carrying stones on building sites.

16 The poster, dated 5 July 1868, which included a text in French and another one in German, has survived; it is entitled: “Manifesto of the International Workingmen's Organisation to its brothers" ("Manifeste de l'Association internationale des travailleurs à ses frères") and is signed "In the name of the Central Committee of the French-speaking Switzerland section: 
a subscription in their favour, at least to pay for the trial fees. To this effect, the address has been printed as a small volume with a circular. We have sent it to the French and German-speaking sections and to the Genevan sections. Later, we received a letter from citizen Varlin, written from the Sainte-Pélagie prison (accompanied with 150 francs from the late subscriptions of the Parisian section for the construction-workers strike). He expressed, in his comrades' names, the desire to drink a glass of this nice little Genevan white wine. We all know that those brave-at-hearts are not exactly happy in prison. Thus the Central Committee has taken this opportunity to treat them. Whilst we await

The Président, Graglia, François. The general secretary, Perret, Henri” ("Au nom du Comité central des sections de la Suisse romande: Le Président, Graglia, François. Le Secrétaire général, Perret, Henri"). The German text is signed in the name of the Central Committee of the German-speaking sections group, by J.P. Becker, president, and Munch, secretary. The poster claims that the members of the Parisian Bureau have been condemned "for having helped and supported their brothers, workers in Geneva, in times of strike and as the decision from the Court stipulates: for having sought to 'better the condition of all the workers, without distinctions of nationality, through cooperation, production and credit.' It is a declaration of war to social ideas and the principles of the 89 Revolution, as the accused Varlin and Combault very well stated in their defence" ("pour avoir aidé et secouru leurs frères, les ouvriers à Genève, en temps de grève, et, comme le dit l'arrêt de la Cour: pour avoir eu pour but 'l'amélioration de la condition de tous les ouvriers, sans distinction de nationalité, par la coopération, la production et le crédit.' C'est une déclaration de guerre aux idées sociales et aux principes de la Révolution de 89, comme l'ont très bien dit les accusés Varlin et Combault dans leur défense.") The duty of Genevan workers was indeed "first of all to invoke public indignation against the actions of such magistracy and call upon all honest men, without exception. Then to prove, through an excess of energy that we are not the unworthy colleagues of those heroic defenders of the people, and that we will not leave them alone on the battlefield. Our honour, especially that of us, workers of Geneva, is engaged, let us thus show through our actions that fraternity is not a vain word to us, and that we are worthy to be part of the great social party, the party of the regeneration of humanity" ("certes, d'invoquer d'abord contre les actes d'une telle magistrature, l'indignation publique, d'en appeler à tous les hommes honnêtes, sans exception de parti. Puis, de prouver, par un surcroît d'énergie, que nous ne sommes pas les indignes confrères de ces défenseurs hérö̈ques de la cause du peuple, et que nous ne les laisserons pas seuls sur la brèche. Notre honneur, surtout à nous, ouvriers de Genève, est engagé, montrons donc par l'action que la fraternité chez nous n'est pas une vaine parole, et que nous sommes dignes d'appartenir au grand parti social, au parti de la régénération de l'humanité."). BGE, Affiches politiques et sociales (1868/83). In accordance with registration copyright, a copy of each poster was deposited in the Bibliothèque de Genève. Folded and piled up, these posters were put in folders, photographed and catalogued around twenty years ago. They can be viewed on microfiche. Those of the IWMA are particularly numerous; many are notifications to attend meetings. 
the day when we are able to give them the greatest testimony of our sympathy and solidarity which closely link us to them, the Committee has unanimously decided to send our friends a barrel of wine accompanied with the fraternal salutations of the twenty-four Genevan sections."17

Strikes, as we can see, promoted a feeling of solidarity and even friendship, spreading from trades to industries, to the whole of a town's working population, through a region, a country, finally reaching an international dimension. The Genevan construction workers' strike of March-April 1868 was recounted, only a month later, by Johann Philipp Becker, in a booklet published in two consecutive editions in German, then translated into French. Following an analysis and denunciation of the lies disseminated by the press, in which he insists on the fundamental capitalist nature of journalistic endeavours, Becker proceeds to a minute and circumstantial account of the events. He exposes all the manoeuvres of the action committee nominated by the IWMA's Central Committee, their efforts to inform public opinion (posters), to maintain contact with the construction-workers and never lose their trust. He explains how the locksmiths and mechanics (non-affiliated to the IWMA), seeing they could benefit from the movement, subsequently went on strike and joined the International. This spontaneous movement went against the tactics of the action committee, who did not seek to spread to other professions a strike it was supporting financially. Everything is described in detail: the bourgeoisie's efforts to stir up the Swiss against non-nationals; the attempts to find an agreement; the government's struggle not to compromise itself; the reception committee at the landing of the boats and at the station to prevent the arrival of blacklegs and finally the war of posters to influence public opinion. Becker attacked those who suggested that co-operatives were a panacea: "if the proletariat, forever extending due to the laws of the current economy, should reach its salvation through cooperative associations alone, Jupiter could revolved around

17 "En outre le Comité a décidé de faire une souscription en leur faveur, au moins pour payer les frais du procès. À cet effet, le manifeste a été imprimé en petit avec une circulaire. Nous l'avons envoyé aux sections romandes et allemandes et aux sections de Genève. Plus tard, nous avons reçu une lettre du citoyen Varlin, écrite de la prison de Sainte-Pélagie (accompagnée de $150 \mathrm{fr}$. provenant des souscriptions en retard de Paris pour la grève des ouvriers du bâtiment). Il a manifesté, au nom de ses camarades, le désir de boire un verre de ce petit vin blanc de Genève. Nous savons tous que ces braves cœurs ne sont pas précisément heureux dans la prison. Aussi le Comité central a-t-il saisi cette occasion de leur faire un petit plaisir. En attendant de leur donner une plus grande preuve de notre sympathie et de la solidarité qui nous lie étroitement à eux, le comité a voté à l'unanimité d'envoyer à nos amis une feuillette de vin accompagnée du salut fraternel des 24 sections de Genève." 
the sun a thousand times before this salvation was achieved, and all civilisations would be buried under the rubble by the next century."18 Reaching a more general conception of the labour movement, "of which striking has only been a small convulsion", Becker laid out his perspectives: "How can we, by ways of legislation, take capital away from usurpation, to distribute it in good order to work, the producer of and legitimate heir to this capital? How can we convert the entire society under intellectual, moral and material premises, in an association of production and consumption? How can we dissolve the State into society and society into the State? Lastly, how can we, with the help of organic laws and their efficient applications, erect solidarity as a right and as a duty? Of course, much sawing and ploughing will be required in order to attain the great harvest. [...] The labour movement does not consist of fitting everybody in a system imagined by a great genius, because all that is not generally produced by logical facts is useless; it is primarily concerned with facilitating the development of facts, of which the new ideological current is only a logical deduction; it is merely its expression in the common man's language, the common ownership of all thinking men."19

The booklet's thirty-nine pages were a remarkable example of the way in which the IWMA learnt lessons from each strike it led and wished to propagate them. It was indeed a pedagogical publication and must be read today with this consideration in mind. The account of the events was faithful, despite the author's bias, and from it a way of doing things and the mistakes to be avoided emerged: in short, a list of advice. The construction-workers strike of 1868 was

18 "Si le prolétariat qui augmente toujours, grâce aux lois de l'économie actuelle devait attendre son salut de l'association coopérative seule, Jupiter pourrait achever mille fois son évolution autour du soleil avant que ce salut se réalise, et toute civilisation serait ensevelie sous les décombres dès le siècle prochain."

"Comment peut-on, par voie de législation, enlever le capital à l'usurpation, pour l'attribuer avec bon ordre au travail, le producteur et l'héritier légitime de ce capital ? Comment peut-on convertir la société tout entière sous le rapport intellectuel, moral et matériel, en une association de production et de consommation. Comment peut-on fondre l'État dans la société et la société dans l'État ? Enfin comment peut-on, à l'aide de lois organiques et d'applications effectives, ériger en droit et en devoir la solidarité ? Certes il faudra beaucoup semer et beaucoup labourer avant d'arriver à la grande récolte. [...] Le mouvement ouvrier ne consiste pas à vouloir enserrer tout le monde dans le cadre d'un système imaginé par un homme de génie, car tout ce qui ne découle pas en général des faits logiques, n'est pas utile; il s'agit principalement de faciliter le développement des faits dont le nouveau courant d'idées n'est qu'une déduction logique, ce n'est que l'expression passée en langue vulgaire, devenue la propriété commune de tous les penseurs." 
thus of great importance for the labour movement. Usually considered and proclaimed a victory, it was sometimes judged in less favourable terms in private, as one can read in the letter of the president of the typographers' society to a Parisian correspondent. After having exposed the compromise which had put an end the conflict, he adds: "It is not so great, as you can see, but at least it is something, especially as it was the first time such a formidable strike broke in Geneva. There were subscriptions all across the various trades, even requests for loan, and I believe that in Paris you know something about this. In short, I believe it was time that the strike stopped, because the International (which I don't wish to belittle, on the contrary, as I am one of its supporters) didn't think it would last that long and consequently had not taken the necessary measures to obtain from the foreign sections the funds it may have needed." 20 Another important episode of the labour struggles led in the name of the International was the strikes organised at the end of 1868 and the beginning of 1869 in Basel. We will only mention in passing the role played by Becker's booklet in this matter. $^{21}$

A final example of a strike which we would like to look into, far less important and thus not known by historians, was that of roofers in Geneva (22 October to 12 December 1869). It is an episode worth mentioning as a book of minutes of the Genevan society of roofers, section of the International Workingmen's Association, ${ }^{22}$ has survived and, together with L'Egalité, it allows us to follow the events from the perspective of the strikers themselves. One should not expect this volume to present the verbatim minutes of the incidents: here the secretary merely retraced the unravelling of the strike after it happened. Roofers were not as educated as typographers. In addition to

20 "Ce n'est pas bien brillant, comme tu le vois, mais enfin c'est quelque chose, surtout pour la première fois qu'une grève aussi formidable éclatait à Genève. Il y a eu des souscriptions ouvertes dans tous les corps de métier de Genève, même des demandes de prêt et je crois qu'à Paris vous en savez quelque chose. En résumé, je crois qu'il était temps que la grève cessât, car l'Internationale (que je ne veux pas débiner, au contraire, car je suis un de ses partisans) n'avait pas cru qu'elle durerait aussi longtemps, et n'avait par conséquent pris assez tôt ses mesures pour se procurer auprès des sections de l'étranger les fonds dont elle pouvait avoir besoin." Archives of the typographers' union, Correspondance reçue 1850-1868, minute of the letter dated 4 July 1868.

21 Wilfried Haeberli, "Der erste Klassenkampf in Basel (Winter 1868/69) und die Tätigkeit der Internationalen Arbeiter-Association (1866-1876)", in Basler Zeitschrift für Geschichte und Altertumskunde, 64 (1964) p. 93 ff.; Die Geschichte der Basler Arbeiterbewegung von den Anfängen bis 1914, Bd 1 (Basel, 1986), p. $20 \mathrm{ff.}$

22 "Livre de Procès-verbaux de la Société des Couvreurs des Genève Section de l'Association Internationale des travailleurs", BGE, manuscripts. 
their fanciful spelling, their writing is a first-hand testimonial of a form of acculturation amongst the working classes - namely the appropriation of certain expressions from the legal vocabulary reminisced from the speeches of employers and from newspapers, and reused more or less successfully, making general understanding often rather arduous. Let us add that some of these roofers were German speakers - out of the thirty-six who joined the section at the end of 1868, nineteen came from German-speaking Switzerland, two from Geneva, eight from the rest of French-Speaking Switzerland, four from neighbouring Savoy, one from Piedmont and two for which the origin is not defined but probably from Geneva. It was a difficult and dangerous profession and rare were the men who lived beyond the age of fifty - of which there were four. It all started with a general assembly of the Genevan sections of the IWMA. As reported in L'Egalité, at the end of a discussion on "the supporting of our French brothers on strike, who, only recently, have so effectively demonstrated their solidarity towards us [...] a roofer informed us that a workshop of nine workers was about to go on strike after their employer had tried to reduce their wages. The roofers' association could support the struggle materially, but only asked the International for moral support." ${ }^{23}$ The paper's editorial team announced that the employer had finally given in, adding: "It is not the first time that, thanks to the International, a strike ends before it even began. Given a little more time they will all end in such a way."24 But the following issue had to refute this previous statement: there had in fact been a strike affecting the entire profession. Indeed, roofers had elaborated a new scale of wages that they had submitted to each employer, giving them until 21 October to agree to it. As none of them had replied, on the morning of 22 October some groups had called on all the construction sites, inciting those who were unaware of the situation to strike and gather at the Temple Unique, the International's headquarters. On the same night, the regional committee of the IwMA had called for all the branch committees to meet and had formally taken the lead of the movement by forming a commission of eight people, including only one

23 "Lappui à fournir à nos frères de France en grève, lesquels nous ont donné, il y a peu de temps, des témoignages si effectifs de solidarité [...] un couvreur nous a fait connaître qu'un atelier de 9 ouvriers allait se mettre en grève par suite de la tentative faite par le patron de réduire le salaire. L'Association des couvreurs était en l'état de soutenir matériellement la lutte, mais elle ne demandait à l'Internationale que l'appui moral." L'Égalité (23 October 1869). The Genevan newspapers mentions numerous strikes during this period: coalminers of Rive-de-Giers, wool-spinners of Elbeuf, weavers of Chazelles-sur-Lyon, miners of Aubin and their massacre, etc....

"Ce n'est pas la première fois que, grâce à l'Internationale, une grève finit ainsi avant d'être commencée. Encore quelque temps et toutes finiront de même." 
roofer it seems. Whilst remarking that this relieved the work of the section, the minutes observed that "in some way we are reduced no longer to be our own masters." 25 The strike was very well organised: every day the members would gather (they had to register at roll call three times a day) and organise patrols on the building sites to stop people from working. It was insured that the bricklayers' and carpenters' branches did not allow their members to accept duties that were those of roofers. Some employers agreed to the new wage and work started again on their sites, which relieved the strain on the section. Nevertheless, after two weeks of struggle, discouragement surfaced. There were a few "false friends", ${ }^{26}$ dissensions and a fight between two militants. Help from the International had to be requested after the section's fund became no longer sufficient. In the end, the representatives of the strike committee and the employers' assembly reached a settlement, the workers having made a concession on the ten-hour day wage: five francs in the city and up to six francs in the country, depending on the distance. The agreement was ratified by the section but "so that they encounter no problems and whispers at a later date, each and everyone, as a proof of their consent to the new wage approved by the employer, had to append their signature." ${ }^{27}$ This strike, small in scale, shows in details how the International functioned and how it led labour struggles, potentially provoking amongst strikers the feeling of no longer being their "own masters".

Not only in the field of strikes would researchers benefit from distancing the history of the International from the traditional frames of analysis, and bring it down to the level of individual members. It is also what they should be doing when studying the conflicts that tore apart the IWMA. Switzerland, as we know, formed a terrain on which, for the first time, the two camps, which later on would give birth to social democracy on one side and anarchism on the other, were confronting each other. But the development and assertion of those two strands took place over a ten-year period and at the start their opposition was not that of two well-defined and coherent doctrines. Therefore one must be careful not to describe the members of the Jura federation as anarchists and their opponent as socialists or even Marxists. Similarly, one must not reduce everything to a Marx-Bakunin conflict. For rank-and-file members of the International, the question depended on their experience and the representations they had elaborated. Our task is to distinguish how protagonists

\footnotetext{
25 "Nous nous trouvons en quelque sorte réduits à ne plus être nos maîtres."

26 "Faux-frères."

27 “[...] pour qu'ils n'aient pas des difficultés et des murmures plus tard, chacun comme preuve du consentement du nouveau tarif approuvé par les patrons a été tenu d'y poser sa signature."
} 
perceived themselves, and how they perceived their opponents. At this level, that of militants and members, things were quite different from elsewhere. In Geneva, the actions of Bakunin and his supporters had offended the majority of members. Their attack on the IWMA's very popular leaders and their attempt at discrediting them because of conceptions which they found retarded, had turned the majority of the International against them. In his romanticism, Bakunin thought he could count on bricklayers and unskilled workers, the majority of whom were seasonal labour from neighbouring Faucigny. This had been a miscalculation: although they differentiated themselves from the more prosperous clockmakers of $\mathrm{La}$ Fabrique, they were not more favourable to the Russian revolutionary's ideas. The abolition of inheritance and the collectivisation of the soil, for instance, cannot have sent waves of enthusiasm through them, either. Bakunin's supporters were perceived as schemers and dissension-breeders, ambitious individuals seeking to seize power by means of a plot within the International. And what had transpired from Bakunin's secret society only confirmed these accusations. This is what is brought to light by the extensive documentation available on the congress of La Chaux-de-Fonds (3-4 April 1870), which ended with the schism of the French-speaking federation.

Belief in a plot existed on the other side, too. Admittedly Guillaume had been able to position himself beyond the small contingencies in order to elaborate a more general conception of the opposition. He did this remarkably in his 1873 Mémoire de la Fédération jurasienne. But in his common propaganda, he also used more basic arguments. Hence, in an article published in the Bulletin de la Fédération jurassienne on 7 March 1872: "there is a scheme within the International, a scheme whose aim is to transform this association into an authoritarian organisation, into an instrument designed to serve the ambition of a few individualities. To achieve this aim, a plan has been instigated to first expel from our Association, after having crushed them under heaps of cleverly spread slander, all the men whose free spirit could have been an obstacle to the success of our future dictators' project."28 The accusation of authoritarianism and the qualification of authoritarian, so frequent amongst "jurassians", will ultimately be turned against them by their opponent.

28 "Il existe une intrigue dans l'Internationale, intrigue dont le but est de transformer cette association en une organisation autoritaire, en un instrument destiné à servir l'ambition de quelques individualités. Le plan adopté pour arriver à ce but est d'expulser au préalable de notre Association, après les avoir écrasés sous des monceaux de calomnies adroitement répandues, tous les hommes dont l'esprit d'indépendance aurait pu être un obstacle à la réussite du projet de nos futurs dictateurs." 
It was in this context that the question of the participation in political struggles was asked. Once again, one must try and see in what terms it impacted upon workers, considering the absence of political parties formed at the national scale and the extreme variety of political landscapes presented by the different areas. There was nothing in common between Basel's radical opposition, incapable, since the 1840 s, of overthrowing the domination of an extremely agile conservative elite, and Zurich's radicalism, representing industrial and rail work, which would be pushed out of power in 1868-1869 by a progressive democratic movement supported by the International. Radicalism was the ruling party of the Neuchâtel district when it had been driven out of power in Geneva, where it was trying to win the favours of the working class, in concordance with its tradition. But the Jura region offered very different situations between the Neuchâtel mountains (La Chaux-de-Fonds, Le Locle, etc.) and Bern Jura (Courtelary, Saint-Imier, etc.), a diversity that Coullery had analysed very well in his time. Thus, amongst the local working class, different traditions and perceptions could be observed which could even be contradictory from one place to the next. 


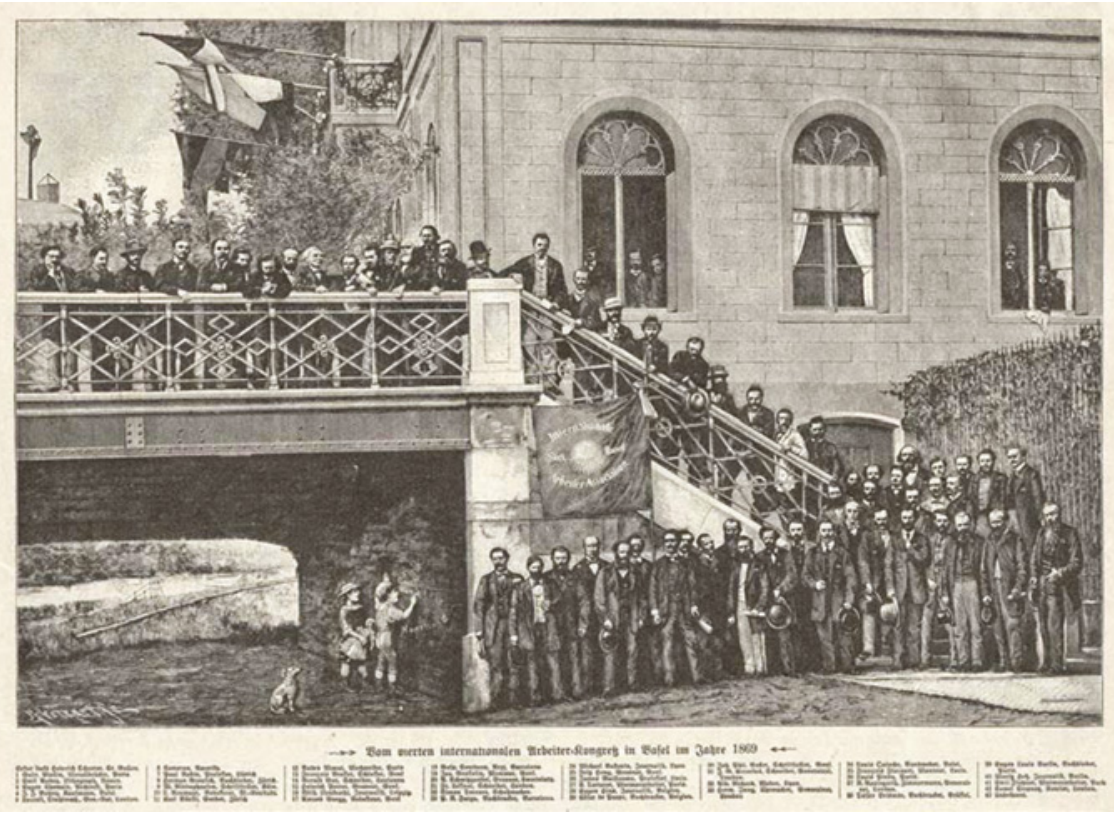

FIGURE 10.1 The delegates to the Basle Conference, 1869. This Conference took place from 6 to 12 September, 1869. There were 75 delegates. The flag is that of the local section Engraving based on a photo. The two boys caricaturing Napoleon have been added by the engraver.

COLLECTION: IISH, AMSTERDAM. 